\title{
Target of Rapamycin Complex 2 Subunit MAPKAP1
}

National Cancer Institute

\section{Source}

National Cancer Institute. Target of Rapamycin Complex 2 Subunit MAPKAP1. NCI

Thesaurus. Code C105119.

Target of rapamycin complex 2 subunit MAPKAP1 (522 aa, $\sim 59 \mathrm{kDa}$ ) is encoded by the human MAPKAP1 gene. This protein is involved in the modulation of growth factordependent signaling. 